\title{
The Sensitivity of Field Populations of Metopolophium dirhodum (Walker) (Hemiptera: Aphididae) to Seven Insecticides in Northern China
}

\author{
Peipan Gong ${ }^{1,2}$, Xinan $\mathrm{Li}^{3}$, Chao Wang ${ }^{2}$, Saige $\mathrm{Zhu}^{2}$, Qiuchi $\mathrm{Li}^{2}$, Yunhui Zhang ${ }^{2}$, Xiangrui Li ${ }^{2}$, Guangkuo Li ${ }^{4}$, \\ Enliang Liu ${ }^{5}$, Haifeng Gao ${ }^{4, *}$, Xueqing Yang ${ }^{1, *}$ and Xun Zhu ${ }^{2, *}$ (i)
}

1 College of Plant Protection, Shenyang Agricultural University, Shenyang 110866, China; gpeipan@webmail.hzau.edu.cn

2 State Key Laboratory for Biology of Plant Diseases and Insect Pests, Institute of Plant Protection, Chinese Academy of Agricultural Sciences, Beijing 100193, China; 18375611798@163.com (C.W.); zsg121011@163.com (S.Z.); liqiuchi0921@163.com (Q.L.); yhzhang@ippcaas.cn (Y.Z.); xrli@ippcaas.cn (X.L.)

3 School of Resource and Environmental Sciences, Henan Institute of Science and Technology, Xinxiang 453003, China; lixinan2019@126.com

4 Key Laboratory of Integrated Pest Management on Crop in Northwestern Oasis, Xinjiang Academy of Ag-ricultural Sciences, Institute of Plant Protection Ministry of Agriculture and Rural Affairs, Urumqi 830091, China; lgk0808@163.com

5 Research Institute of Grain Crops, Xinjiang Academy of Agricultural Sciences, Urumqi 830091, China; liuenliang_513@163.com

* Correspondence: ghf20044666@163.com (H.G.); sling@hotmail.com (X.Y.); zhuxun@caas.cn (X.Z.)

check for updates

Citation: Gong, P.; Li, X.; Wang, C.; Zhu, S.; Li, Q.; Zhang, Y.; Li, X.; Li, G.; Liu, E.; Gao, H.; et al. The Sensitivity of Field Populations of Metopolophium dirhodum (Walker) (Hemiptera: Aphididae) to Seven Insecticides in Northern China. Agronomy 2021, 11, 1556. https://doi.org/10.3390/ agronomy11081556

Academic Editor: Stefano Bedini

Received: 29 June 2021

Accepted: 27 July 2021

Published: 4 August 2021

Publisher's Note: MDPI stays neutral with regard to jurisdictional claims in published maps and institutional affiliations.

Copyright: (C) 2021 by the authors Licensee MDPI, Basel, Switzerland. This article is an open access article distributed under the terms and conditions of the Creative Commons Attribution (CC BY) license (https:/ / creativecommons.org/licenses/by/ $4.0 /)$.

\begin{abstract}
Insect pests are primarily controlled by insecticides. However, the sensitivity decreases and insecticide resistance is problematic for the effective management of agriculturally important insects, including Metopolophium dirhodum, which is an aphid that commonly feeds on cereals. The insecticide sensitivity status and potential resistance of $M$. dirhodum field populations remain relatively unknown. In this study, the susceptibility of $19 \mathrm{M}$. dirhodum populations from seven provinces in Northern China to neonicotinoids, pyrethroids, organophosphates, and a macrolide (abamectin) was determined in 2017-2019. The results indicated that two populations were highly resistant to thiamethoxam, with a relative resistance ratio (RLR) of 134.03 and 103.03, whereas one population was highly resistant to beta-cypermethrin (RLR of 121.42). On the basis of the RLR, the tested M. dirhodum populations ranging from susceptible to showing moderate levels of resistance to imidacloprid (RLR of 1.50 to 57.29), omethoate (RLR of 1.07 to 18.73), and abamectin (RLR of 1.10 to 25.89), but they were ranging from susceptible to showing tolerance or low levels of resistance to bifenthrin (RLR of 1.14 to 6.02) and chlorpyrifos (RLR of 1.11 to 7.59). Furthermore, a pair-wise correlation analysis revealed a significant correlation between the median lethal concentrations $\left(\mathrm{LC}_{50}\right)$ for beta-cypermethrin and thiamethoxam, reflecting the cross-resistance between these two insecticides. The data obtained in our study provide timely information about aphid insecticide sensitivity, which may be used to delay the evolution of $M$. dirhodum insecticide resistance in Northern China.
\end{abstract}

Keywords: Metopolophium dirhodum; insecticide sensitivity; neonicotinoids; pyrethroids; correlation analysis

\section{Introduction}

Aphids are important sap-feeding agricultural pests that adversely affect cereal, vegetable, and fruit crops worldwide. Approximately $2 \%$ of the Aphididae species (100 of 5000) have successfully exploited agricultural ecosystems, resulting in substantial economic losses [1]. For example, Metopolophium dirhodum (Walker) is a common aphid on winter cereals [2,3]. This aphid, which is native to the Holarctic region, has been the most common cereal aphid species in Europe for many years, but it is now distributed worldwide [4,5]. 
Metopolophium dirhodum serves as a vector for several viruses (e.g., Barley Yellow Dwarf Virus) that can infect cereals [6]. The economic damage caused by M. dirhodum is well documented in countries where it is prevalent [7-9]. Rhopalosiphum padi and Sitobion avenae are the dominant aphid populations in the wheat-growing regions of China, whereas $M$. dirhodum is mainly distributed in the cooler areas in the northwestern part of the country. Despite the narrower distribution of $M$. dirhodum, our field surveys and bioassays have revealed it is more resistant to neonicotinoid insecticides [10]. In China, M. dirhodum was first detected in the 1980s, but interest in this insect was limited because it was a major pest only in parts of the western wheat-growing region (e.g., Rikaze, Tibet, China) [11]. However, M. dirhodum has recently migrated eastward, resulting in increased crop yield reduction $[12,13]$.

Insecticides remain an important component of many pest management programs $[13,14]$. Neonicotinoids, pyrethroids, organophosphates, and macrolides are important groups of synthetic insecticides that are widely used to control arthropod pests [15]. Insecticide resistance has been reported for various aphid species, including Myzus persicae [16,17], Aphis fabae [18], and Aphis gossypii [19]. Previous studies confirmed that field populations of two wheat aphid species, R. padi and S. avenae, have evolved varying levels of resistance to insecticides with diverse modes of action [20,21]. An insecticide resistance diagnostic kit for Sogatella furcifera recently developed on the basis of insecticide resistance monitoring data has enabled rapid analyses under field conditions [22].

Neonicotinoids are currently used against sap-feeding insect pests, although their usage has been banned or restricted in Europe, and restricted in some states in the USA, due to concerns about side effects on bees and other pollinators [23-25]. Furthermore, Nilaparvata lugens field populations are highly resistant to neonicotinoids, which has resulted in the frequent inability to prevent infestations by this insect [26]. In addition to neonicotinoidresistant pests, disease vector insects highly resistant to pyrethroids have been reported, including Anopheles sinensis, Anopheles funestus, and Anopheles gambiae [27-29]. The longterm use of pyrethroids has resulted in the emergence of cotton-melon aphid (A. gossypii) populations highly resistant to these insecticides [30]. The organophosphate insecticides were frequently used for managing Schizaphis graminum in the 1990s [31]. Abamectin resistance has been detected in Plutella xylostella, Bemisia tabaci, and Tetranychus urticae [32-34]. Consequently, overcoming insecticide resistance is an ongoing challenge for sustainable pest management.

Despite the significant economic losses caused by M. dirhodum, little is known about the sensitivity of $M$. dirhodum to the insecticides commonly used in China to control this pest. In this study, we tested the susceptibility of $19 \mathrm{M}$. dirhodum field populations collected in seven provinces in Northern China in 2017-2019 to seven insecticides from various classes (i.e., neonicotinoids, pyrethroids, organophosphates, and macrolides). A pair-wise correlation analysis revealed some cross-resistance between thiamethoxam and $\beta$-cypermethrin. The data presented in this paper provide timely information regarding the insecticide resistance status of $M$. dirhodum, and may be useful for restricting the evolution of insecticide resistance in this important aphid species.

\section{Materials and Methods}

\subsection{Insect Populations and Insecticides}

Metopolophium dirhodum samples were collected from wheat fields in Northern China (Figure 1, Table 1). A total of 19 populations were collected from 2017 to 2019 from the following regions: Guide, Qinghai (population code: QIG); Shizuishan, Ningxia (NIS); Yangling, Shaanxi (SHY); Linfen, Shanxi (SHL); Liaocheng, Shandong (SDL); Dezhou, Shandong (SDD); Kashgar prefecture, Xinjiang (XIK); Langfang, Hebei (HLF); Baoding, Hebei (HBD); Dingzhou, Hebei (HDZ); Shijiazhuang, Hebei (HSZ); Xingtai, Hebei (HXT); Handan, Hebei (HHD); and Cangzhou, Hebei (HCZ). 


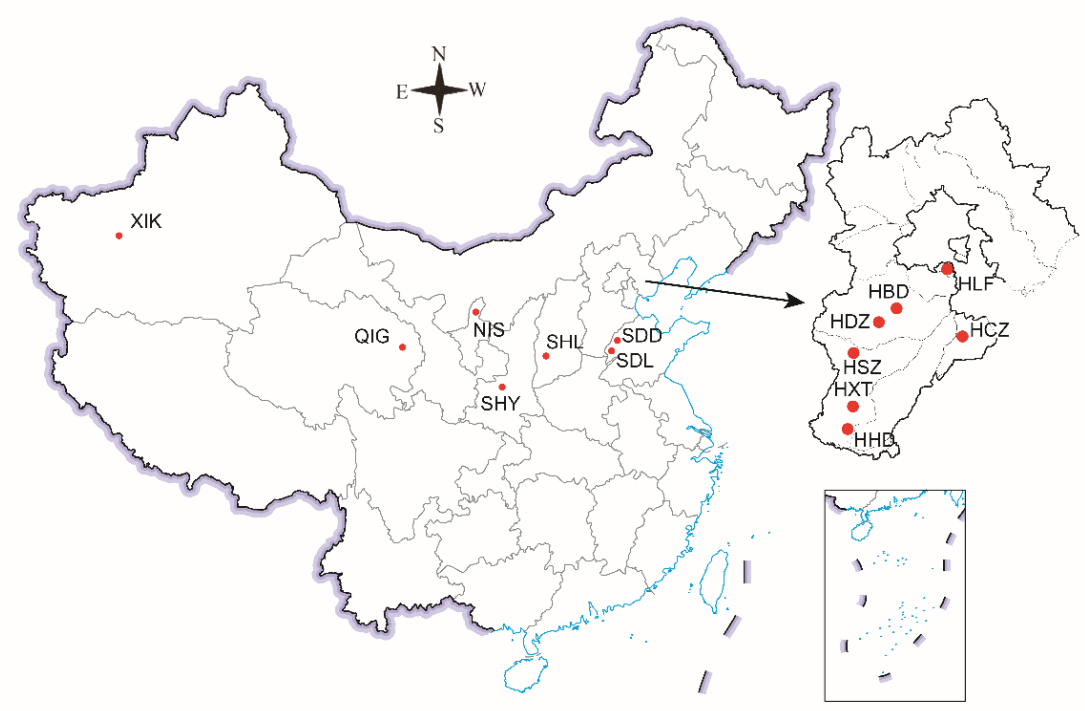

Figure 1. Metopolophium dirhodum sample collection regions in Northern China.

Table 1. Information regarding the collected Metopolophium dirhodum field populations.

\begin{tabular}{|c|c|c|c|c|c|c|}
\hline No. & Collecting Locality & Code & Collection Date & Longitude and Latitude & HIS $^{a}$ & Reference \\
\hline 1 & Dingzhou, Hebei & HDZ & 17 May 2017 & $38^{\circ} 31^{\prime} 09^{\prime \prime} \mathrm{N}, 115^{\circ} 04^{\prime} 09^{\prime \prime} \mathrm{E}$ & unknown & - \\
\hline 2 & Shijiazhuang, Hebei & HSZ & 17 May 2017 & $37^{\circ} 54^{\prime} 59^{\prime \prime} \mathrm{N}, 114^{\circ} 45^{\prime} 19^{\prime \prime} \mathrm{E}$ & unknown & - \\
\hline 3 & Xingtai, Hebei & HXT & 18 May 2017 & $37^{\circ} 05^{\prime} 04^{\prime \prime} \mathrm{N}, 114^{\circ} 36^{\prime} 21^{\prime \prime} \mathrm{E}$ & unknown & - \\
\hline 4 & Handan, Hebei & HHD & 18 May 2017 & $36^{\circ} 32^{\prime} 31^{\prime \prime} \mathrm{N}, 114^{\circ} 33^{\prime} 32^{\prime \prime} \mathrm{E}$ & unknown & - \\
\hline 5 & Cangzhou, Hebei & $\mathrm{HCZ}$ & 26 April 2017 & $38^{\circ} 03^{\prime} 14^{\prime \prime} \mathrm{N}, 116^{\circ} 40^{\prime} 25^{\prime \prime} \mathrm{E}$ & neonicotinoids & [35] \\
\hline 6 & Langfang, Hebei & HLF & 30 April 2017 & $39^{\circ} 30^{\prime} 29^{\prime \prime} \mathrm{N}, 116^{\circ} 36^{\prime} 09^{\prime \prime} \mathrm{E}$ & neonicotinoids & [13] \\
\hline 7 & Baoding, Hebei & HBD & 29 April 2017 & $39^{\circ} 12^{\prime} 56^{\prime \prime} \mathrm{N}, 115^{\circ} 47^{\prime} 54^{\prime \prime} \mathrm{E}$ & unknown & - \\
\hline 8 & Dezhou, Shandong & SDD & 18 May 2017 & $36^{\circ} 57^{\prime} 45^{\prime \prime} \mathrm{N}, 115^{\circ} 58^{\prime} 01^{\prime \prime} \mathrm{E}$ & \multirow{2}{*}{$\begin{array}{c}\text { neonicotinoids } \\
\text { pyrethroids } \\
\text { organophosphates }\end{array}$} & \multirow[t]{2}{*}{ [36] } \\
\hline 9 & Liaocheng, Shandong & SDL & 18 May 2017 & $36^{\circ} 28^{\prime} 18^{\prime \prime} \mathrm{N}, 115^{\circ} 39^{\prime} 23^{\prime \prime} \mathrm{E}$ & & \\
\hline \multirow[t]{2}{*}{10} & \multirow[t]{2}{*}{ Yangling, Shaanxi } & \multirow[t]{2}{*}{ SHY } & 3 May 2018 & $34^{\circ} 15^{\prime} 33^{\prime \prime} \mathrm{N}, 108^{\circ} 02^{\prime} 33^{\prime \prime} \mathrm{E}$ & \multirow{2}{*}{$\begin{array}{c}\text { neonicotinoids } \\
\text { pyrethroids } \\
\text { organophosphates } \\
\text { macrolides }\end{array}$} & \multirow[t]{2}{*}{ [37] } \\
\hline & & & 13 May 2019 & $34^{\circ} 15^{\prime} 33^{\prime \prime} \mathrm{N}, 108^{\circ} 02^{\prime} 33^{\prime \prime} \mathrm{E}$ & & \\
\hline \multirow[t]{2}{*}{11} & \multirow[t]{2}{*}{ Linfen, Shanxi } & \multirow[t]{2}{*}{ SHL } & 14 May 2018 & $36^{\circ} 06^{\prime} 38^{\prime \prime} \mathrm{N}, 111^{\circ} 30^{\prime} 04^{\prime \prime} \mathrm{E}$ & \multirow{2}{*}{$\begin{array}{c}\text { neonicotinoids } \\
\text { pyrethroids } \\
\text { organophosphates }\end{array}$} & \multirow[t]{2}{*}{ [38] } \\
\hline & & & 14 May 2019 & $36^{\circ} 06^{\prime} 38^{\prime \prime} \mathrm{N}, 111^{\circ} 30^{\prime} 04^{\prime \prime} \mathrm{E}$ & & \\
\hline \multirow{2}{*}{12} & \multirow{2}{*}{ Kashi, Xinjiang } & \multirow{2}{*}{ XIK } & 7 June 2018 & $38^{\circ} 11^{\prime} 25^{\prime \prime} \mathrm{N}, 77^{\circ} 11^{\prime} 12^{\prime \prime} \mathrm{E}$ & \multirow{2}{*}{$\begin{array}{c}\text { neonicotinoids } \\
\text { organophosphates }\end{array}$} & \multirow{2}{*}[39,40]{} \\
\hline & & & 28 May 2019 & $38^{\circ} 11^{\prime} 25^{\prime \prime} \mathrm{N}, 77^{\circ} 11^{\prime} 12^{\prime \prime} \mathrm{E}$ & & \\
\hline \multirow{2}{*}{13} & \multirow{2}{*}{ Shizuishan, Ningxia } & \multirow{2}{*}{ NIS } & 12 June 2018 & $39^{\circ} 05^{\prime} 57^{\prime \prime} \mathrm{N}, 106^{\circ} 44^{\prime} 51^{\prime \prime} \mathrm{E}$ & \multirow{2}{*}{$\begin{array}{c}\text { pyrethroids } \\
\text { organophosphates }\end{array}$} & \multirow{2}{*}{ [41] } \\
\hline & & & 16 June 2019 & $39^{\circ} 05^{\prime} 57^{\prime \prime} \mathrm{N}, 106^{\circ} 44^{\prime} 51^{\prime \prime} \mathrm{E}$ & & \\
\hline \multirow[t]{2}{*}{14} & \multirow[t]{2}{*}{ Guide, Qinghai } & \multirow[t]{2}{*}{ QIG } & 14 June 2018 & $36^{\circ} 02^{\prime} 15^{\prime \prime} \mathrm{N}, 101^{\circ} 27^{\prime} 13^{\prime \prime} \mathrm{E}$ & \multirow{2}{*}{$\begin{array}{c}\text { neonicotinoids } \\
\text { pyrethroids } \\
\text { organophosphates }\end{array}$} & \multirow[t]{2}{*}{ [42] } \\
\hline & & & 18 June 2019 & $36^{\circ} 02^{\prime} 15^{\prime \prime} \mathrm{N}, 101^{\circ} 27^{\prime} 13^{\prime \prime} \mathrm{E}$ & & \\
\hline
\end{tabular}


The following seven insecticides from five different classes were used in this study: $97 \%$ thiamethoxam, 96\% imidacloprid, 95\% beta-cypermethrin, 97\% bifenthrin, 95\% abamectin, and $97 \%$ chlorpyrifos (Beijing Green Agricultural Science and Technology Group Co., Ltd., Beijing, China), and 40\% omethoate (emulsifiable) (Hebei Xinxing Chemical Co., Ltd., Baoding, China).

\subsection{Bioassays}

Bioassays were conducted using aphids that were within three generations of being collected from fields. A previously described leaf-dip method [10] was used for the insecticide bioassays. Briefly, the insecticide active ingredients were diluted six or seven times using $0.1 \%$ Tween-80 (prepared in water). Wheat leaves containing apterous adult aphids (excluding alatae) were dipped in the diluted insecticide solutions for $3 \mathrm{~s}$. Three replicates of 30-50 aphids were used for each concentration. The mortality rate was calculated for each treatment. Aphids that did not move after being touched by a writing brush were considered dead.

\subsection{Statistical Analysis}

Concentration-mortality data were subjected to a probit analysis, with the data corrected for natural mortality [43]. The median lethal concentration $\left(\mathrm{LC}_{50}\right), 95 \%$ confidence interval, and slope were calculated using the IBM SPSS program (version 20). The relative resistance ratio (RLR) for each insecticide was calculated on the basis of the median lethal concentration $\left(\mathrm{LC}_{50}\right)$ for the most susceptible field population. The following RLR respectively indicated low, moderate, and high insecticide resistance: RLR $\leq 10,10<\mathrm{RLR} \leq 100$, and RLR $>100$. Pairwise correlation coefficients for the $\log \mathrm{LC}_{50}$ values of the field populations treated with imidacloprid, thiamethoxam, beta-cypermethrin, abamectin, and omethoate were calculated according to Pearson's correlation analysis using the SPSS software (IBM Corp., Armonk, NY, USA) to determine the cross-resistance among the insecticides.

\section{Results}

\subsection{Susceptibility Baseline of M. dirhodum to Seven Insecticides}

At present, the baseline values for insecticide resistance in Metopolophium dirhodum have not been determined. In this study, the relative resistance ratio for each insecticide was calculated on the basis of the $\mathrm{LC}_{50}$ for the most susceptible field population because of the lack of use on a contemporary susceptible reference strain during the bioassay (Table 2).

Table 2. Susceptibility baseline of Metopolophium dirhodum to seven insecticides.

\begin{tabular}{|c|c|c|c|c|c|c|}
\hline Insecticides & Population & $\mathbf{N}^{\mathbf{a}}$ & $\mathrm{LC}_{50}(95 \% \mathrm{CI} ; \mathrm{mg} / \mathrm{L})^{\mathrm{b}}$ & Slope \pm SE & $p$-Value & Correlation Coefficient \\
\hline Thiamethoxam & HBD-2017 & 1849 & $4.27(2.27-8.03)$ & $4.64 \pm 0.10$ & 0.0001 & 0.9810 \\
\hline Imidacloprid & SDD-2017 & 1817 & $3.93(2.55-6.05)$ & $4.71 \pm 0.05$ & 0.0001 & 0.9940 \\
\hline Beta-cypermethrin & NIS-2019 & 713 & $0.52(0.48-0.56)$ & $0.58 \pm 0.05$ & 0.0001 & 0.9999 \\
\hline Omethoate & SHL-2019 & 460 & $18.63(8.44-41.03)$ & $0.75 \pm 0.12$ & 0.0087 & 0.9625 \\
\hline Bifenthrin & QIG-2019 & 543 & $9.47(5.68-15.80)$ & $0.57 \pm 0.05$ & 0.0017 & 0.9874 \\
\hline Chlorpyrifos & SHY-2019 & 702 & $0.44(0.31-4066)$ & $2.33 \pm 0.37$ & 0.0083 & 0.9637 \\
\hline Abamectin & HHD-2019 & 2109 & $1.60(0.97-2.63)$ & $4.80 \pm 0.12$ & 0.0014 & 0.9697 \\
\hline
\end{tabular}

${ }^{a}$ Number of tested aphids. ${ }^{b}$ Median lethal concentration and $95 \%$ confidence interval.

\subsection{Monitoring Sensitivity to Seven Insecticides in Northern China}

The relative resistance levels varied among the field populations collected from various locations in Northern China (Figure 2). For the neonicotinoids, the NIS-2018 and SHY-2018 populations were highly resistant to thiamethoxam, with an RLR of 134.03 and 103.30, respectively. Additionally, 16 populations were ranging from susceptible to showing moderate levels of resistance to thiamethoxam, with an RLR of 2.04-46.77, whereas only four populations were moderately resistant to imidacloprid, with an RLR of 10.95-57.29 and 14 populations ranging from susceptible to showing tolerance or low levels of re- 
sistance, with an RLR of 1.50-5.56. (Table 3). The bioassay results for the pyrethroids indicated that the NIS-2018 population was highly resistant to beta-cypermethrin, with an RLR of 121.42 , but 15 populations were ranging from susceptible to showing moderate levels of resistance, with an RLR of 2.40-96.75. However, the tested populations were equally susceptible to bifenthrin. Regarding the susceptibility to the older generation organophosphate insecticides, the SHL-2018 and NIS-2019 populations were moderately resistant to omethoate, with an RR of 18.73 and 11.82, respectively. An analysis of the susceptibility to chlorpyrifos revealed that the tested populations were equally susceptible (Table 4). Moreover, 18 populations were ranging from susceptible to showing moderate levels of resistance to abamectin, with an RLR of 1.10-25.89 (Table 5).

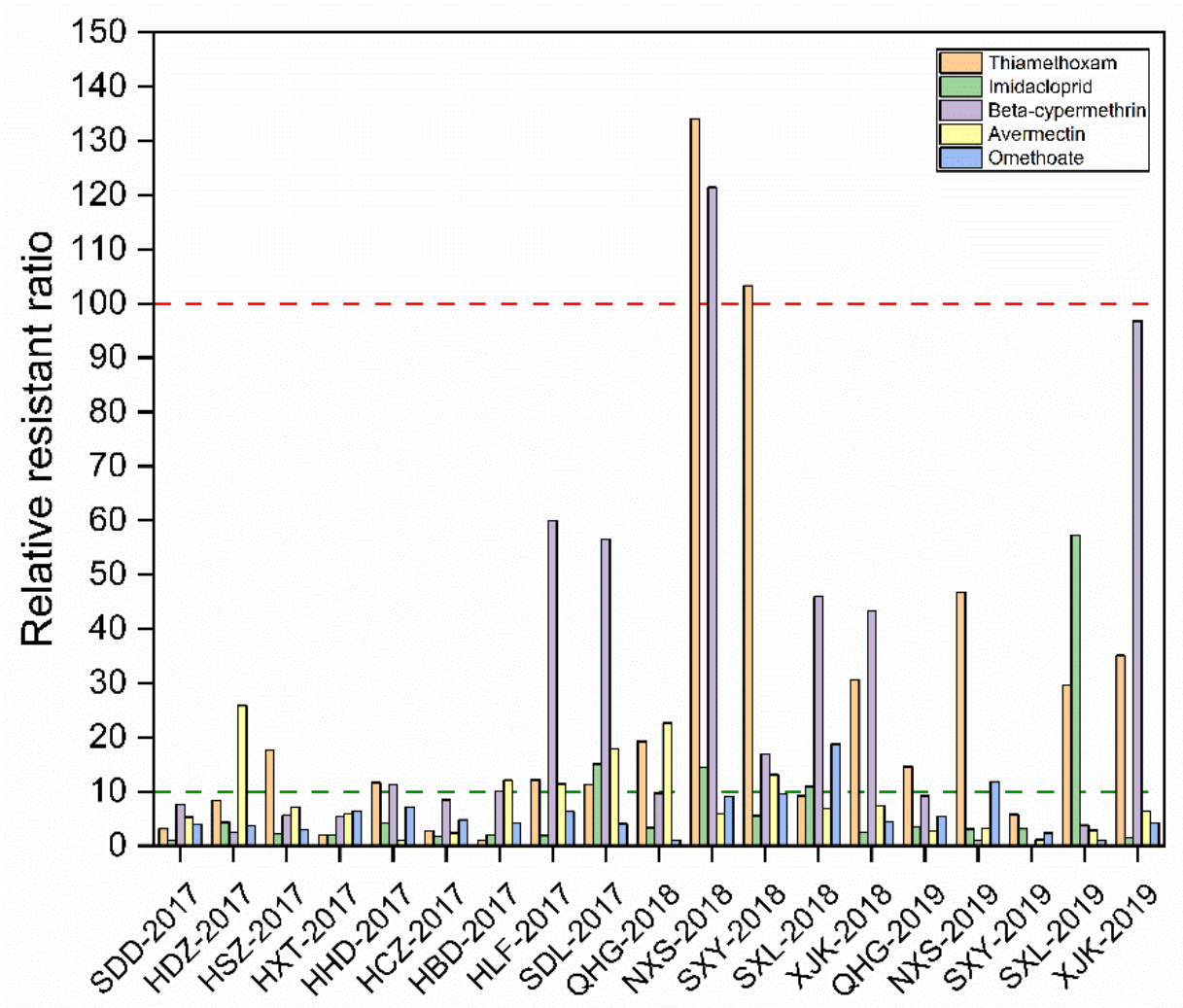

Figure 2. Relative resistance levels of Metopolophium dirhodum field populations. 
Table 3. Susceptibility of Metopolophium dirhodum field populations to imidacloprid and thiamethoxam.

\begin{tabular}{|c|c|c|c|c|c|c|c|c|c|c|c|c|}
\hline \multirow[b]{2}{*}{ Population } & \multicolumn{6}{|c|}{ Thiamethoxam } & \multicolumn{6}{|c|}{ Imidacloprid } \\
\hline & $\mathrm{N}^{\mathrm{a}}$ & $\mathrm{LC}_{50}(95 \% \mathrm{CI} ; \mathrm{mg} / \mathrm{L})^{\mathrm{b}}$ & Slope \pm SE & $p$-Value & $\begin{array}{l}\text { Correlation } \\
\text { Coefficient }\end{array}$ & $\underset{c}{R L R}$ & $\mathbf{N}$ & $\mathrm{LC}_{50}(95 \% \mathrm{CI} ; \mathrm{mg} / \mathrm{L})$ & Slope \pm SE & $p$-Value & $\begin{array}{l}\text { Correlation } \\
\text { Coefficient }\end{array}$ & RLR $^{c}$ \\
\hline SDD-2017 & 1857 & $13.42(7.42-24.95)$ & $4.23 \pm 0.13$ & 0.0009 & 0.9753 & 3.14 & 1817 & $3.93(2.55-6.05)$ & $4.71 \pm 0.05$ & 0.0001 & 0.9940 & 1.00 \\
\hline HSZ-2017 & 843 & 75.25 (58.19-97.31) & $3.31 \pm 0.13$ & 0.0006 & 0.9934 & 17.62 & 2212 & $8.51(5.31-13.63)$ & $4.38 \pm 0.09$ & 0.0009 & 0.9919 & 2.17 \\
\hline HXT-2017 & 1951 & $8.71(6.58-11.54)$ & $4.21 \pm 0.08$ & 0.0001 & 0.9939 & 2.04 & 1578 & $8.072 .63-24.75)$ & $4.46 \pm 0.20$ & 0.0177 & 0.9543 & 2.05 \\
\hline HHD-2017 & 1746 & $49.56(7.22-16.59)$ & $3.99 \pm 0.14$ & 0.0001 & 0.9780 & 11.61 & 1742 & $16.72(11.55-24.21)$ & $4.02 \pm 0.08$ & 0.0004 & 0.9951 & 4.25 \\
\hline HCZ-2017 & 1968 & 11.39 (7.04-18.43) & $4.38 \pm 0.10$ & 0.0001 & 0.9839 & 2.67 & 1562 & $6.86(4.00-11.78)$ & $4.46 \pm 0.08$ & 0.0001 & 0.9907 & 1.75 \\
\hline HBD-2017 & 1849 & $4.27(2.27-8.03)$ & $4.64 \pm 0.10$ & 0.0001 & 0.9810 & 1.00 & 2692 & $7.72(3.97-14.93)$ & $4.41 \pm 0.12$ & 0.0004 & 0.9840 & 1.96 \\
\hline SDL-2017 & 1726 & $48.10(31.28-73.95)$ & $3.54 \pm 0.14$ & 0.0005 & 0.9826 & 11.26 & 1236 & 59.24 (35.46-98.98) & $3.63 \pm 0.23$ & 0.0008 & 0.9561 & 15.07 \\
\hline QIG-2018 & 2426 & 82.33 (29.86-227.01) & $0.48 \pm 0.12$ & 0.0293 & 0.9151 & 19.28 & 925 & $13.09(9.37-18.29)$ & $4.03 \pm 0.11$ & 0.0005 & 0.9943 & 3.33 \\
\hline NIS-2018 & 550 & 572.29 (281.45-1163.67) & $0.78 \pm 0.10$ & 0.0045 & 0.9759 & 134.03 & 654 & $56.63(14.41-222.55)$ & $3.79 \pm 0.49$ & 0.0594 & 0.8634 & 14.41 \\
\hline SHY-2018 & 766 & 441.11 (150.42-1293.56) & $0.53 \pm 0.11$ & 0.0173 & 0.9404 & 103.30 & 511 & $21.87(11.14-42.95)$ & $4.39 \pm 0.11$ & 0.0070 & 0.9674 & 5.56 \\
\hline SHL-2018 & 2289 & $39.32(25.96-59.56)$ & $0.62 \pm 0.06$ & 0.0020 & 0.9860 & 9.22 & 1145 & $43.05(38.63-47.97)$ & $4.02 \pm 0.03$ & 0.0005 & 0.9995 & 10.95 \\
\hline XIK-2018 & 560 & 130.48 (100.43-169.51) & $0.86 \pm 0.06$ & 0.0006 & 0.9939 & 30.56 & 913 & $9.51(3.71-24.40)$ & $4.43 \pm 0.20$ & 0.0085 & 0.9630 & 2.42 \\
\hline QIG-2019 & 780 & $62.29(44.18-87.82)$ & $0.77 \pm 0.06$ & 0.0010 & 0.9913 & 14.59 & 686 & $13.96(5.07-38.44)$ & $0.99 \pm 0.20$ & 0.0150 & 0.9459 & 3.54 \\
\hline NIS-2019 & 689 & $199.72(120.76-330.31)$ & $0.88 \pm 0.09$ & 0.0019 & 0.9864 & 46.77 & 515 & $12.23(8.24-18.15)$ & $0.59 \pm 0.06$ & 0.0111 & 0.9889 & 3.11 \\
\hline SHY-2019 & 546 & $24.58(10.99-55.00)$ & $0.40 \pm 0.07$ & 0.0116 & 0.9545 & 5.76 & 603 & $12.29(9.41-16.05)$ & $0.80 \pm 0.05$ & 0.0004 & 0.9951 & 3.13 \\
\hline SHL-2019 & 660 & 126.19 (56.44-282.15) & $0.68 \pm 0.10$ & 0.0065 & 0.9691 & 29.55 & 556 & $225.16(114.66-442.15)$ & $1.02 \pm 0.24$ & 0.1494 & 0.9726 & 57.29 \\
\hline
\end{tabular}

a Number of aphids used in bioassays. ${ }^{\mathrm{b}}$ Median lethal concentration and $95 \%$ confidence interval. ${ }^{\mathrm{c}}$ Relative resistance ratio. 
Table 4. Susceptibility of Metopolophium dirhodum field populations to beta-cypermethrin, bifenthrin, omethoate, and chlorpyrifos

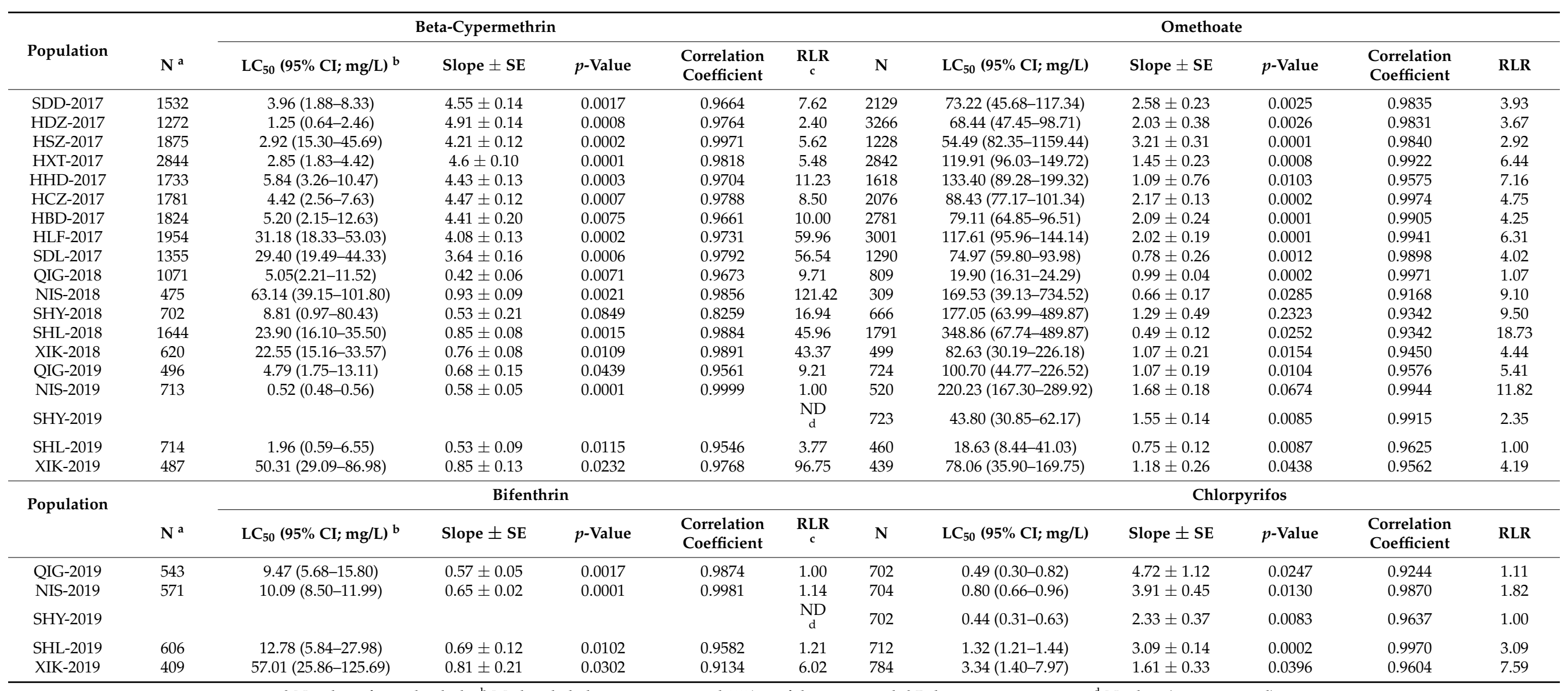

${ }^{a}$ Number of tested aphids. ${ }^{b}$ Median lethal concentration and $95 \%$ confidence interval. ${ }^{c}$ Relative resistance ratio. ${ }^{d}$ No data (i.e., not tested). 
Table 5. Susceptibility of Metopolophium dirhodum field populations to abamectin.

\begin{tabular}{|c|c|c|c|c|c|c|}
\hline Population & $\mathbf{N}^{\mathrm{a}}$ & $\mathrm{LC}_{50}(95 \% \mathrm{CI} ; \mathrm{mg} / \mathrm{L})^{b}$ & Slope \pm SE & $p$-Value & Correlation Coefficient & $\operatorname{RLR}^{\mathrm{c}}$ \\
\hline HHD-2017 & 2109 & $1.60(0.97-2.63)$ & $4.80 \pm 0.12$ & 0.0014 & 0.9697 & 1.00 \\
\hline HDZ-2017 & 1399 & $41.42(23.49-73.04)$ & $3.46 \pm 0.19$ & 0.0056 & 0.9719 & 25.89 \\
\hline HSZ-2017 & 1722 & 11.35 (7.17-17.98) & $3.72 \pm 0.18$ & 0.0050 & 0.9741 & 7.09 \\
\hline HХT-2017 & 1740 & $9.44(6.13-14.55)$ & $4.18 \pm 0.12$ & 0.0001 & 0.9805 & 5.90 \\
\hline SDD-2017 & 2189 & $8.46(5.62-12.74)$ & $3.43 \pm 0.24$ & 0.0009 & 0.9752 & 5.29 \\
\hline HCZ-2017 & 1918 & $3.82(2.34-6.24)$ & $4.09 \pm 0.19$ & 0.0010 & 0.9735 & 2.39 \\
\hline HBD-2017 & 2245 & 19.35 (13.91-26.90) & $3.91 \pm 0.08$ & 0.0005 & 0.9941 & 12.09 \\
\hline HLF-2017 & 1258 & $18.22(12.70-26.14)$ & $4.00 \pm 0.00$ & 0.0021 & 0.9852 & 11.39 \\
\hline SDL-2017 & 1103 & $28.57(20.78-39.29)$ & $2.39 \pm 0.36$ & 0.0014 & 0.9695 & 17.86 \\
\hline QIG-2018 & 1488 & 36.19 (17.33-75.59) & $0.92 \pm 0.15$ & 0.0087 & 0.9624 & 22.62 \\
\hline NIS-2018 & 771 & $9.52(2.69-33.60)$ & $0.81 \pm 0.21$ & 0.0311 & 0.9116 & 5.95 \\
\hline SHY-2018 & 621 & $21.01(10.13-43.6)$ & $1.18 \pm 0.19$ & 0.0087 & 0.9623 & 13.13 \\
\hline SHL-2018 & 1847 & $11.03(4.36-27.89)$ & $0.67 \pm 0.13$ & 0.0145 & 0.9823 & 6.89 \\
\hline XIK-2018 & 696 & $11.88(9.24-15.29)$ & $1.07 \pm 0.06$ & 0.0003 & 0.9957 & 7.43 \\
\hline QIG-2019 & 580 & $4.28(2.57-7.12)$ & $0.97 \pm 0.09$ & 0.0016 & 0.9880 & 2.68 \\
\hline NIS-2019 & 676 & $5.23(4.48-6.09)$ & $1.78 \pm 0.09$ & 0.0024 & 0.9976 & 3.27 \\
\hline SHY-2019 & 750 & $1.76(0.88-3.49)$ & $0.81 \pm 0.10$ & 0.0035 & 0.9795 & 1.10 \\
\hline SHL-2019 & 576 & $4.53(3.52-5.84)$ & $1.49 \pm 0.12$ & 0.0060 & 0.9940 & 2.83 \\
\hline XIK-2019 & 687 & $10.20(7.23-14.40)$ & $1.04 \pm 0.07$ & 0.0008 & 0.9923 & 6.38 \\
\hline
\end{tabular}

${ }^{a}$ Number of aphids used in bioassays. ${ }^{\mathrm{b}}$ Median lethal concentration and $95 \%$ confidence interval. ${ }^{\mathrm{c}}$ Relative resistance ratio.

\subsection{Insecticide Resistance at Five Locations in 2018-2019}

The insecticide susceptibility of $M$. dirhodum collected from the same region in 2018 and 2019 was analyzed (Figure 3). Our results indicated that the sensitivity of M. dirhodum to five tested insecticides fluctuated between 2018 and 2019. More specifically, although the 2-year analysis revealed similar resistance levels in most regions, substantial differences between years were detected for the resistance to thiamethoxam in NIS and SHY (Figure 3B), the resistance to beta-cypermethrin in NIS and SHL (Figure 3C), the resistance to omethoate in SHL (Figure 3D), and the resistance to abamectin in QIG and SHY (Figure 3E).

Pair-wise correlation between the $\log \mathrm{LC}_{50}$ values of different insecticides.

There were no significant correlations among the evaluated insecticides, with the exception of a significant positive correlation between thiamethoxam and beta-cypermethrin (Table 6).

Table 6. Pair-wise correlation analysis of the $\mathrm{LC}_{50}$ values of five insecticides for 19 Metopolophium dirhodum field populations.

\begin{tabular}{ccccc}
\hline Insecticides & Imidacloprid & Thiamethoxam & $\beta$-Cypermethrin & Abamectin \\
\hline Thiamethoxam & 0.165 & & & \\
$\beta$-cypermethrin & 0.023 & $0.504^{*}$ & & \\
Abamectin & -0.119 & -0.041 & 0.024 & \\
Omethoate & -0.132 & 0.283 & 0.247 & -0.193 \\
\hline * Positive correlation between LC $_{50}$ values (0.05 significance level). &
\end{tabular}




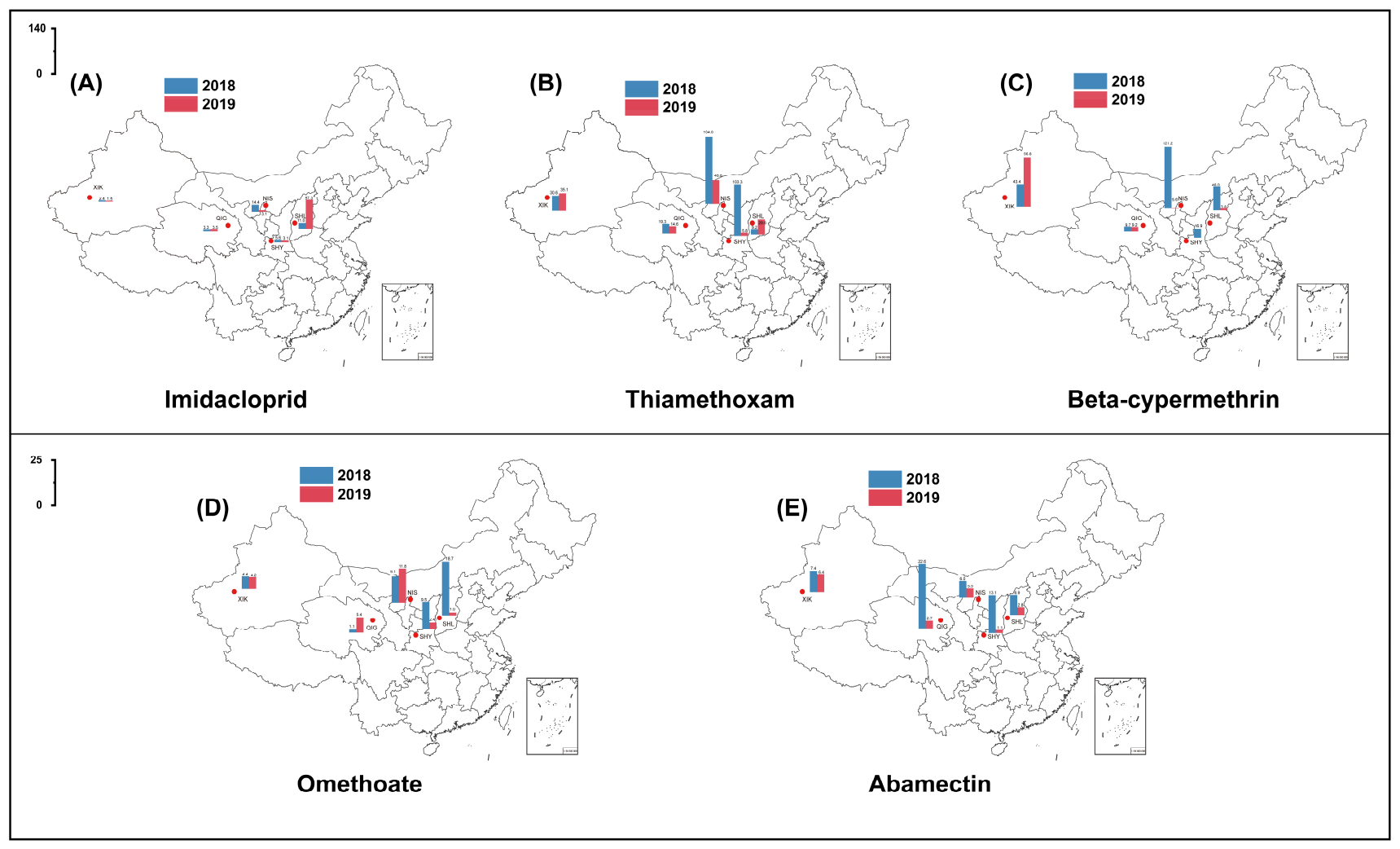

Figure 3. Insecticide susceptibility of Metopolophium dirhodum collected at the same sites in 2018 and 2019, (A) Imidacloprid; (B) Thiamethoxam; (C) Beta-cypermethrin; (D) Omethoate; (E) Abamectin. Blue and red bars represent the resistance ratios in 2018 and 2019, respectively.

\section{Discussion}

Previous research determined the baseline toxicities of insecticides used to control wheat aphids as well as the corresponding susceptibility levels $[15,20,21]$. In the current study, we analyzed the susceptibility of the wheat aphid M. dirhodum to insecticides by comparing the lethal concentrations of various insecticides for 19 field populations. We also evaluated the resistance of $M$. dirhodum collected from 14 regions in Northern China to seven commonly used insecticides and determined the likelihood of cross-resistance among five insecticides.

Our results indicated that some $M$. dirhodum populations (4 of 19) exhibited moderate levels of resistance to imidacloprid. Additionally, two populations (NIS-2018 and SHY2018) were highly resistant to thiamethoxam. An earlier investigation assessing the effect of coating seeds with imidacloprid on laboratory populations of four wheat aphids confirmed that the seed treatment could effectively control R. padi, S. avenae, and S. graminum, but not M. dirhodum [13]. This is particularly important considering $M$. dirhodum may overtake $R$. padi and S. avenae as the primary aphid species on wheat plants derived from neonicotinoidtreated seeds [10]. Furthermore, different wheat aphids often harm crops at the same time. Consequently, the effect of neonicotinoid seed treatments on the prevention and control of M. dirhodum infestations in the field will need to be investigated. The data presented herein may be useful for optimizing the use of neonicotinoids and decreasing the environmental effects associated with the application of multiple pesticides.

Regarding pyrethroids, the limited M. dirhodum populations collected in 2019 exhibited low or no resistance to bifenthrin. In contrast, higher levels of resistance to betacypermethrin were detected, including one highly resistant population and moderately resistant populations. Clearly, determining the likelihood an insecticide will fail to control M. dirhodum is warranted. In Argentina, the most widely used insecticides for controlling 
M. dirhodum are chlorpyrifos, dimethoate, and pirimicarb [44]. Organophosphates were used to control M. dirhodum for a long time, but they are rarely used now [45]. Moreover, because organophosphates effectively minimized damages caused by M. dirhodum, there has been relatively little attention paid to this aphid species. The bioassay results of the current study, in which $M$. dirhodum was susceptible to organophosphates, were as expected. Additionally, M. dirhodum was also relatively susceptible to abamectin.

To improve the prevention and control of $M$. dirhodum infestations, we examined the resistance patterns among pesticides to identify the best compounds for managing $M$. dirhodum. Significant cross-resistance was detected between $\beta$-cypermethrin and thiamethoxam. A thiamethoxam-resistant cotton aphid strain reportedly developed increasing resistance to several pyrethroids [46]. A recent study proved that the resistance to $\lambda$-cyhalothrin is related to the resistance to thiamethoxam in R. padi [47]. Some cytochrome P450 monooxygenase genes encoding CYP6 and CYP3 family members are associated with the resistance to both neonicotinoids and pyrethroids [48,49]. Furthermore, there is evidence that NADPHcytochrome P450 contributes to the resistance to $\beta$-cypermethrin and imidacloprid in $N$. lugens [50]. Despite the intensive use of chemical treatments, $M$. dirhodum has still managed to invade new areas and damage crops in northern China [13]. Previously or seldomly used insecticides are still effective for managing pests, including pyrethroids, organophosphates, sulfoximines (e.g., sulfoxaflor), and macrolides (e.g., abamectin).

\section{Conclusions}

Our results suggest that $M$. dirhodum field populations are resistant to the neonicotinoid and pyrethroid insecticides most frequently used to control this aphid species in SHY (Yangling, Shaanxi) and NIS (Shizuishan, Ningxia) of China. The efficacy of neonicotinoid seed treatments for controlling $M$. dirhodum should be evaluated in future studies. Our bioassay results indicate that abamectin and bifenthrin are effective against $M$. dirhodum and can be used as alternatives to insecticides to which M. dirhodum has evolved high levels of resistance. Unfortunately, rotating the use of thiamethoxam and beta-cypermethrin to control M. dirhodum in parts of China should probably be limited. Overall, we recommend that monitoring and control programs should be strengthened in regions where $M$. dirhodum is distributed.

Author Contributions: Conceptualization, X.Z., H.G. and X.Y.; methodology, X.Z. and P.G.; software, P.G.; formal analysis, P.G. and X.L. (Xinan Li); investigation P.G., X.L. (Xinan Li), C.W., S.Z. and Q.L.; writing—original draft preparation, P.G.; writing—review and editing, E.L., G.L., X.Z., Y.Z. and X.L. (Xiangrui Li). All authors have read and agreed to the published version of the manuscript.

Funding: This research was funded by the National Key Research and Development Program of China (2017YFD0200303), China Agriculture Research System of MOF and MARA (CARS-3), and the Training Program for outstanding young talents in science and technology of Xinjiang Uygur Autonomous Region (2018Q041), SINOGRAIN II (CHN-17/0019): Technological Innovation to Support Environmentally-Friendly Food Production and Food Safety Under a Changing ClimateOpportunities and Challenges for Norway-China Cooperation.

Institutional Review Board Statement: Not applicable.

Informed Consent Statement: Not applicable.

Data Availability Statement: Most of the recorded data are available in all Tables in the manuscript.

Acknowledgments: We thank Liwen Bianji for editing the English text of a draft of this manuscript.

Conflicts of Interest: The authors declare no conflict of interest.

\section{References}

1. Simon, J.C.; Peccoud, J. Rapid evolution of aphid pests in agricultural environments. Curr. Opin. Insect. Sci. 2018, $26,17-24$. [CrossRef]

2. Weber, G. On the ecological genetics of Metopolophium dirhodum (Walker) (Hemiptera, Aphididae). Zeits. Ange. Entomol. 1985, 100, 451-458. [CrossRef] 
3. Saska, P.; Skuhrovec, J.; Tylová, E.; Platková, H.; Tuan, S.-J.; Hsu, Y.-T.; Vítámvás, P. Leaf structural traits rather than drought resistance determine aphid performance on spring wheat. J. Pest. Sci. 2021, 94, 423-434. [CrossRef]

4. Honek, A.; Martinkova, Z.; Saska, P.; Dixon, A.F.G. Aphids (Homoptera: Aphididae) on winter wheat: Predicting maximum abundance of Metopolophium dirhodum. J. Econ. Entomol. 2018, 111, 1751-1759. [CrossRef] [PubMed]

5. Li, X.; Gong, P.; Wang, B.; Wang, C.; Li, M.; Zhang, Y.; Li, X.; Gao, H.; Ju, J.; Zhu, X. Selection and validation of experimental condition-specific reference genes for qRT-PCR in Metopolophium dirhodum (Walker) (Hemiptera: Aphididae). Sci. Rep. 2020, 10, 21951. [CrossRef]

6. Chapin, J.W.; Thomas, J.S.; Gray, S.M.; Smith, D.M.; Halbert, S.E. Seasonal abundance of aphids (Homoptera: Aphididae) in wheat and their role as barley yellow dwarf virus vectors in the South Carolina coastal plain. J. Econ. Entomol. 2001, 94, 410-421. [CrossRef] [PubMed]

7. Sepúlveda, D.A.; Zepeda-Paulo, F.; Ramírez, C.C.; Lavandero, B.; Figueroa, C.C. Diversity, frequency, and geographic distribution of facultative bacterial endosymbionts in introduced aphid pests. Insect. Sci. 2017, 24, 511-521. [CrossRef] [PubMed]

8. Clement, S.L.; Elberson, L.R.; Youssef, N.; Evans, F.L.Y.A. Cereal aphid and natural enemy populations in cereal production systems in Eastern Washington. J. Kans. Entomol. Soc. 2004, 77, 165-173. [CrossRef]

9. Havlíková, H. Character and extent of damage to winter wheat cultivars caused by cereal aphids. J. Rostl. Vyroba. 1997, 43, 113-116.

10. Gong, P.; Chen, D.; Wang, C.; Li, M.; Li, X.; Zhang, Y.; Li, X.; Zhu, X. Susceptibility of four species of aphids in wheat to seven insecticides and its relationship to detoxifying enzymes. Front. Physiol. 2021, 11, 623612. [CrossRef]

11. Hu, S.; Gong, S. Effect of temperature on growth of laboratory population of Metopolophium dirhodum. Acta. Entomol. Sin. 1985, 01, 36-44.

12. Chen, J.; Xia, Y.; Ni, H.; Ding, H.; Cao, Y. Study on population dynamics among field population of Metopolophium dirhodum. J. Plant. Prot. 1994, 21, 7-13.

13. Li, Y.; Li, X.; Zhang, Y.; Zhu, X.; Cheng, D. Impact of seed coating with imidacloprid on laboratory populations of Metopolophium dirhodum (Walker) (Homoptera: Aphididae). Plant. Prot. 2019, 45, 25-29.

14. Miao, J.; Du, Z.; Wu, Y.; Gong, Z.; Jiang, Y.; Duan, Y.; Li, T.; Lei, C. Sub-lethal effects of four neonicotinoid seed treatments on the demography and feeding behaviour of the wheat aphid Sitobion avenae. Pestic. Manag. Sci. 2014, 70, 55-59. [CrossRef]

15. Zuo, Y.; Wang, K.; Zhang, M.; Peng, X.; Piñero, J.C.; Chen, M. Regional susceptibilities of Rhopalosiphum padi (Hemiptera: Aphididae) to ten insecticides. Fla. Entomol. 2016, 99, 269-275. [CrossRef]

16. Mingeot, D.; Hautier, L.; Jansen, J.P. Structuration of multilocus genotypes associated with insecticide resistance of the peach potato aphid, Myzus persicae (Sulzer), in potato fields in southern Belgium. Pestic. Manag. Sci. 2021, 77, 482-491. [CrossRef] [PubMed]

17. Margaritopoulos, J.T.; Kati, A.N.; Voudouris, C.C.; Skouras, P.J.; Tsitsipis, J.A. Long-term studies on the evolution of resistance of Myzus persicae (Hemiptera: Aphididae) to insecticides in Greece. Bull. Entomol. Res. 2021, 111, 1-16. [CrossRef] [PubMed]

18. Mirza, F.K.; Yarahmadi, F.; Jalal-Abadi, A.L.; Meraaten, A.A. Enzymes mediating resistance to chlorpyriphos in Aphis fabae (Homoptera: Aphididae). Ecotoxicol. Environ. Saf. 2020, 206, 111335. [CrossRef] [PubMed]

19. Pan, Y.; Wen, S.; Chen, X.; Gao, X.; Zeng, X.; Liu, X.; Tian, F.; Shang, Q. UDP-glycosyltransferases contribute to spirotetramat resistance in Aphis gossypii Glover. Pestic. Biochem. Physiol. 2020, 166, 104565. [CrossRef] [PubMed]

20. Zhang, L.P.; Lu, H.; Guo, K.; Yao, S.M.; Cui, F. Insecticide resistance status and detoxification enzymes of wheat aphids Sitobion avenae and Rhopalosiphum padi. Sci. China Life Sci. 2017, 60, 1-4. [CrossRef]

21. Gong, P.; Li, X.; Gao, H.; Wang, C.; Li, M.; Zhang, Y.; Li, X.; Liu, E.; Zhu, X. Field evolved resistance to pyrethroids, neonicotinoids, organophosphates and macrolides in Rhopalosiphum padi (Linnaeus) and Sitobion avenae (Fabricius) from China. Chemosphere 2021, 269, 128747. [CrossRef]

22. Mao, K.; Ren, Z.; Li, W.; Liu, C.; Xu, P.; He, S.; Li, J.; Wan, H. An insecticide resistance diagnostic kit for whitebacked planthopper Sogatella furcifera (Horvath). J. Pest. Sci. 2021, 94, 531-540. [CrossRef]

23. Flores, J.M.; Gámiz, V.; Gil-Lebrero, S.; Rodríguez, I.; Navas, F.J.; García-Valcárcel, A.I.; Cutillas, V.; Fernández-Alba, A.R.; Hernando, M.D. A three-year large scale study on the risk of honey bee colony exposure to blooming sunflowers grown from seeds treated with thiamethoxam and clothianidin neonicotinoids. Chemosphere 2021, 262, 127735. [CrossRef] [PubMed]

24. Tsvetkov, N.; Samson-Robert, O.; Sood, K.; Patel, H.S.; Malena, D.A.; Gajiwala, P.H.; Maciukiewicz, P.; Fournier, V.; Zayed, A. Chronic exposure to neonicotinoids reduces honey bee health near corn crops. Science 2017, 356, 1395-1397. [CrossRef]

25. Ludicke, J.C.; Nieh, J.C. Thiamethoxam impairs honey bee visual learning, alters decision times, and increases abnormal behaviors. Ecotoxicol. Environ. Saf. 2020, 193, 110367. [CrossRef]

26. Garrood, W.T.; Zimmer, C.T.; Gorman, K.J.; Nauen, R.; Bass, C.; Davies, T.G. Field-evolved resistance to imidacloprid and ethiprole in populations of brown planthopper Nilaparvata lugens collected from across South and East Asia. Pestic. Manag. Sci. 2016, 72, 140-149. [CrossRef]

27. Ding, Y.R.; Yan, Z.T.; Si, F.L.; Li, X.D.; Mao, Q.M.; Asghar, S.; Chen, B. Mitochondrial genes associated with pyrethroid resistance revealed by mitochondrial genome and transcriptome analyses in the malaria vector Anopheles sinensis (Diptera: Culicidae). Pestic. Manag. Sci. 2019, 76. [CrossRef] [PubMed] 
28. Stevenson, B.J.; Bibby, J.; Pignatelli, P.; Muangnoicharoen, S.; O'Neill, P.M.; Lian, L.-Y.; Müller, P.; Nikou, D.; Steven, A.; Hemingway, J.; et al. Cytochrome P450 6M2 from the malaria vector Anopheles gambiae metabolizes pyrethroids: Sequential metabolism of deltamethrin revealed. Insect. Biochem. Mol. Biol. 2011, 41, 492-502. [CrossRef]

29. Chanda, J.; Saili, K.; Phiri, F.; Stevenson, J.C.; Mwenda, M.; Chishimba, S.; Mulube, C.; Mambwe, B.; Lungu, C.; Earle, D.; et al. Pyrethroid and Carbamate Resistance in Anopheles funestus Giles along Lake Kariba in Southern Zambia. Am. J. Trop. Med. Hyg. 2020, 103, 90-97. [CrossRef] [PubMed]

30. Chen, X.; Tie, M.; Chen, A.; Ma, K.; Li, F.; Liang, P.; Liu, Y.; Song, D.; Gao, X. Pyrethroid resistance associated with M918L mutation and detoxifying metabolism in Aphis gossypii from Bt cotton growing regions of China. Pestic. Manag. Sci. 2017, 73, 2353-2359. [CrossRef]

31. Zhu, K.Y.; Gao, J.-R. Kinetic properties and variability of esterases in organophosphate-susceptible and-resistant greenbugs, Schizaphis graminum (Homoptera: Aphididae). J. Pestici. Biochem. 1998, 62, 135-145. [CrossRef]

32. Liang, P.; Gao, X.W.; Zheng, B.Z. Genetic basis of resistance and studies on cross-resistance in a population of diamondback moth, Plutella xylostella (Lepidoptera: Plutellidae). Pestic. Manag. Sci. 2003, 59, 1232-1236. [CrossRef]

33. Wang, Z.; Yao, M.; Wu, Y. Cross-resistance, inheritance and biochemical mechanisms of imidacloprid resistance in B-biotype Bemisia tabaci. Pestic. Manag. Sci. 2009, 65, 1189-1194. [CrossRef]

34. Xu, D.; Zhang, Y.; Zhang, Y.; Wu, Q.; Guo, Z.; Xie, W.; Zhou, X.; Wang, S. Transcriptome profiling and functional analysis suggest that the constitutive overexpression of four cytochrome P450s confers resistance to abamectin in Tetranychus urticae from China. Pestic. Manag. Sci. 2021, 77, 1204-1213. [CrossRef]

35. Li, X.; Zhang, Y.; Xie, X.; Gao, X. Monitoring of wheat aphid resistance to insecticides in China. Barl Cere Sci. 2018, 35, 61.

36. Yu, Z.; Zhang, S.; Song, S.; Zhu, Q.; Xie, C.; Ji, J.; Gao, X. Resistance of wheat aphids to six insecticides and assessment of their field efficacy. Acta Entomo Sin. 2016, 59, 1206-1212.

37. Huang, Y.; Wang, Y.; Wei, J.; Guo, X.; Li, L.; Wang, K.; Chen, M. Insecticide resistance monitoring of Rhopalosiphum padi to seven insecticides from wheat fields of Guanzhong area in Shaanxi province. Plant. Prot. 2019, 45, 211-214.

38. Wu, Y.; Cao, Y.; Zhao, F.; Xing, K. Resistance risk of sitobion avenae to common insecticides in linfen wheat area. J. Shanxi Agric. Sci. 2019, 47, 1061-1064.

39. Liu, W.; Tu, X.; Xu, J.; Tu, X.; Bu, A.; Hou, L. Preliminary report on field chemical control of wheat aphid in winter wheat area of Hotan region. Xinjiang Agric. Sci. 2007, 44, 148-149.

40. Zhao, K.; Hu, J. Occurrence and control of wheat aphid in Kashgar, Xinjiang. Plant. Prot. 1980, 05, 11-13.

41. Hong, B.; Guan, X.; Chi, Y.; Shi, H.; Wen, Z. Bioassay of the sensitivity of wheat aphids to several insecticides in Ningxia. J. Agric. Sci. 2004, 03, 17-20.

42. Dong, W.; Zhang, H.; Chen, A.; Yan, J.; Wei, Y.; Ma, K.; Pu, L.; Cao, S.; Shi, X. Resistance levels to five insecticides of wheat aphid field populations from some regions of Gansu and Qinghai province of China. Agrochemicals 2020, 59, 532-536.

43. Abbott, W.S. A method of computing the effectiveness of an insecticide. J. Econ. Entomol. 1925, 18, 265-267. [CrossRef]

44. Chopa, C.S.; Descamps, L.R. Composition and biological activity of essential oils against Metopolophium dirhodum (Hemiptera: Aphididae) cereal crop pest. Pestic. Manag. Sci. 2012, 68, 1492-1500. [CrossRef] [PubMed]

45. Wang, L. Strategic measures to ban and replace the sustainable development of China's pesticide industry. Pestic. Mark. News 2007, 1, 4-6.

46. Wei, X.; Pan, Y.; Xin, X.; Zheng, C.; Gao, X.; Xi, J.; Shang, Q. Cross-resistance pattern and basis of resistance in a thiamethoxamresistant strain of Aphis gossypii Glover. Pestic. Biochem. Physiol. 2017, 138, 91-96. [CrossRef] [PubMed]

47. Wang, K.; Bai, J.; Zhao, J.; Su, S.; Liu, L.; Han, Z.; Chen, M. Super-kdr mutation M918L and multiple cytochrome P450s associated with the resistance of Rhopalosiphum padi to pyrethroid. Pestic. Manag. Sci. 2020, 76, 2809-2817. [CrossRef]

48. Zhu, F.; Parthasarathya, R.; Bai, H.; Woithe, K.; Kaussmann, M.; Naima, R.; Harrison, D.; Palli, S. A brain-specific cytochrome P450 responsible for the majority of deltamethrin resistance in the QTC279 strain of Tribolium castaneum. Proc. Natl. Acad. Sci. USA 2010, 107, 8557-8562. [CrossRef]

49. Lu, K.; Song, Y.; Zeng, R. The role of cytochrome P450-mediated detoxification in insect adaptation to xenobiotics. Curr. Opin. Insect. Sci. 2021, 43, 103-107. [CrossRef] [PubMed]

50. Liu, S.; Liang, Q.M.; Zhou, W.W.; Jiang, Y.D.; Zhu, Q.Z.; Yu, H.; Zhang, C.X.; Gurr, G.M.; Zhu, Z.R. RNA interference of NADPH-cytochrome P450 reductase of the rice brown planthopper, Nilaparvata lugens, increases susceptibility to insecticides. Pestic. Manag. Sci. 2015, 71, 32-39. [CrossRef] [PubMed] 